\title{
研究論文
}

\section{9. 原子炉燃料棒の流体振動に関する理論解析}

\author{
生田目 健*
}

\author{
（1968年 6 月6日受 理） \\ (1968年 8 月24日 再受理) \\ Theoretical Analysis of Fuel Rod Vibration Induced \\ by Parallel Coolant Flow
}

By Ken NAMATAME

\begin{abstract}
A theoretical analysis was made of fuel rod vibration in a nuclear reactor coolant channel with water flowing parallel to the rod axis. The analysis was based on the fact that the force inducing the fuel rod vibration is the pressure fluctuation of water flowing in the channel, and that this pressure fluctuation travels along the channel with a speed proportional to the mean water velocity.

Using the result of the present analysis, a comparison was made with previous experimental results. It was found that the present analysis could very well explain the observed behavior of rod vibration, and that it could further serve in deducing other characteristics so far remaining unclarified.
\end{abstract}

\section{I 、まえがき}

液体金属を冷却材とする高速炉の開発に際して解決 しなければならない問題の 1 つ燃料棒の振動があ る。燃料棒の振動は，燃料棒とその軸方向に流れる冷 却材に上ってその流れに直角方向に誘発させられるる ので，特に高速炉でこの上らな㜣料棒の振動が問題と なるのは，高速炉の燃料棒が他の型式の原子炉の燃料 棒に比べて剛性の低いことに由来する。この上うな燃 料棒の振動は，核的にも熱的にも望をしいことでな く，その解明と防止に努力が払われている。

然料棒の，この上うな流体の流れによって起こされ る振動に関する，これまでの研究については，すでに 報告したが(1)，ここではその主要点を示す。これまで の実験的な研究に打いては，燃料棒を模擬した中空あ るいは中実の棒を，1本または数本流路内に配置し， そこに水を流すことによって実験を行なっている。棒 の振動周波数は水の流速やその他の条件に無関係で, 棒の水中に批ける自然周波数あるいはそれに近い周波
数であるとするすの や，空気中における自然周波数

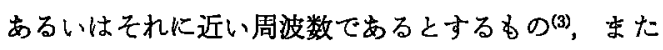
振動周波数が水の流速に比例するとするすの出，など 各研究者により一致していない。さらに, Pavlica ら(3) やQuinn ${ }^{(4)}$ の実験データを検討すると，棒の振動周波 数は常に単一周波数とは限らず，他の周波数成分子重 合した不規則振動の場合もある。さらに著者が長さ $100 \mathrm{~cm}$, 外径 $1 \mathrm{~cm}$ のアクリル棒を内徍 $2.75 \mathrm{~cm}$ の流路 の中心に置きこれ水を流してアクリル棒の振動を 抵抗線歪計で検出し，それを電磁オッシログラフに記 録した結果からも，棒の振動が常に規則振動でないの が観察できた。棒の振幅の最大值を求める実験式は Burgreen らと Paidoussis により提示されている。 Burgreen $5^{(2)}$ の実験式

$$
\left(\frac{\delta}{2 \cdot D_{h}}\right)^{1.3}=0.83 \times 10^{-10} \times\left(K \cdot \Gamma^{1 / 2} \cdot \Omega\right)(1)
$$

(1)式で $K, \Gamma, \Omega$ は(2)式で与えられる無次元数で ある。

* 日本原子力研究所(Japan At. Energy Res. Inst.) 


$$
\begin{aligned}
& K=\frac{10+\alpha \cdot l}{2+\alpha \cdot l}, \quad \alpha \cdot l=\frac{-2 \cdot \beta \cdot l}{\tan \frac{\beta \cdot l}{2}+\tanh \frac{\beta \cdot l}{2}} \\
& f_{n}=\frac{(\beta \cdot l)^{2}}{2 \pi \cdot l^{2}} \cdot \sqrt{\frac{E \cdot I}{\rho_{r} A}} \\
& \Gamma=\frac{\rho_{w} \cdot \bar{v}^{2} \cdot l^{4}}{E \cdot I}, \quad \Omega=\frac{\rho_{w} \cdot \bar{v}^{2}}{\mu \cdot \omega}
\end{aligned}
$$

Paidoussis ${ }^{(5)}$ の実験式

$$
\left(\frac{\delta}{2 d_{2}}\right)=a^{-4} \cdot \frac{\left(u^{2} \cdot \varepsilon^{2} \cdot R e\right)^{4 / 5}}{1+2 u^{2}} \cdot\left(\frac{\beta^{2 / 3}}{1+4 \beta}\right) \times 10^{-5}
$$

(3)式で $a, u, \varepsilon, \beta$ は(4)式で与学られる。

$$
\begin{aligned}
a^{2} & =2 \pi f_{n} \cdot\left(\frac{(m+M) \cdot l^{4}}{E \cdot I}\right)^{1 / 2}, u=\bar{v} \cdot l \cdot\left(\frac{M}{E \cdot I}\right)^{1 / 2} \\
\varepsilon & =\frac{l}{d_{2}}, \quad \beta=\frac{M}{M+m}
\end{aligned}
$$

これらの実験式で，棒の振幅がその横方向の剛性と 両端の支持条件とに関係するのは通常の棒の強制横振 動の問題と同様であるが，ここで特徵的なのは,さらに 流路の水力直径, 水の平均流速, 密度扣よび粘性係数に 関係することである。てしてこれまでの研究では，流 路の水力直径, 水の平均流速, 密度および粘性係数の振 幅に対する影響については，各研究者の実験結果は一 致していない(第1表参照)。したがって，さらに棒の 振幅に対するこれらの影響を明確にするには，流路内 を流れる水がどのよ5にして棒の振動を誘発するか， その機構を明らかにし，さらにそれに基つく解析が必

\begin{tabular}{|c|c|c|c|c|}
\hline & 流速の影響 & 粘性係数の影響 & 水の密度の影響 & 水力直径の影響 \\
\hline Burgreen らの研究(2) & $\bar{v}^{2.3}$ & $\mu^{-0.77}$ & $\rho_{w}^{1.15}$ & $D_{h}^{1,0}$ \\
\hline Pavlicaらの研究(9) & $\bar{v}^{2.0} \sim \bar{v}^{3.0}$ & 小さい & $\longrightarrow$ & - \\
\hline Quinnの研究(4) & $\bar{v} s^{0}$ & 関係しない & 関係しない & - \\
\hline Paidoussisらの研究(5) & $\bar{v}^{2.1} /\left(C_{1}+C_{2} \bar{v}\right)^{2.0}$ & $\mu^{-0.8}$ & - & $D_{h}^{0.8}$ \\
\hline
\end{tabular}
要である。本報では，このような棒の振動が流路内の 水流のどのような作用で発生するかそのモデルを示 し，それから得られる結果についてこれまでの研究と 比較検討する。

第 1 表これまでの研究の主な結果

\section{II. 理 論と解析}

ここでは，円形断面の流路内に丸棒が同心状に执か れ，てこを水が流れる場合を考える。(第 1 図参照)

\section{1. 棒の振動を誘発する原因}

第 1 図のよ 万に置かれた棒が，どの上うな外力の作 用で振動するかその原因をいくつかあげることができ

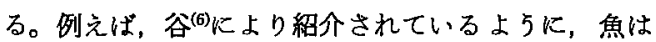
水中を泳ぐとき体をくねらすが，棒の場合はこれと全 く逆の作用で振動するとして解析する方法, あるいは 棒のわずかの偏心で流路両側の断面積が非対称となり 両側で水の流動条件が変わり，そのために棒が振動す るとして解析する方法はどがあるしかし、このよ らなことから棒の振動を説明するのは困難で，ここで は次のような解析モデルにより説明を試みる。

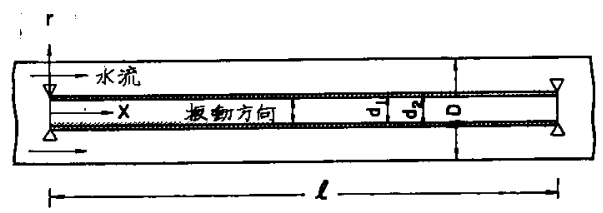

第 1 図 流路内て振動する棒
（1）流路内の水の流れは乱流で，壁面の圧力 $p(t)$ は

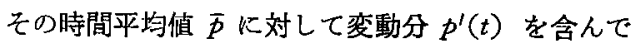
扣り $p(t)=\bar{p}+p^{\prime}(t)$ の上らに示され( 変動分 $p^{\prime}(t)$ 方棒の振動の外力として働く。

(2) この圧力変動 $p^{\prime}(t)$ は流路内を水の平均流速 $\bar{v} の$ 0.9 倍の速さで移動する。( $v_{p}=0.9 \bar{v} こ の$ 点について は次項で考察)

このような性質の外力が作用したときの外力と棒の 振動との関係はすでに知られており ${ }^{(8)}$ （5)式のよう に示される。

$$
\frac{S_{y}(x, f)}{S_{p}(f)}=\left|\int_{0}^{l} \alpha_{x x_{A}} e^{i \omega_{x_{A}} / v_{p} \cdot d x_{A}}\right|^{2}
$$

$S_{p}(f)$ は压力変動 $p^{\prime}(t)$ のスペクトル分布, $S_{y}(x$, $f$ ) は棒の $x=x$ に拈ける振動のスペクトル分布, $\alpha_{x x_{A}}$ は Receptance と呼ばれ， $x=x_{A}$ に外力 $P_{0} \cdot e^{i \omega \varepsilon}$ が作用したときの棒の $x=x$ に括ける振動解を $y_{0} \cdot e^{i \omega_{t}}$ とすると $\alpha_{x x_{A}}=y_{0} / P_{0}$ で示される(第 2 図参照)。流 路内の水の流れの圧力変動は不規則振動であり(例え ば第 3 図参照)，したがって，棒について子不規則振 動が予想されるので（5)式のような不規則振動解析 の関係式が必要となる。 


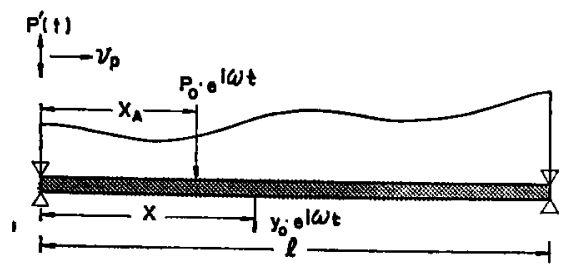

第 2 図 標の座標系

(5) 式から棒の振動特性 $S_{y}(x, f)$ を知るには，圧 力変動のスペクトル特性 $S_{p}(f)$ と右辺の絶対值の性 質を解明する必要がある。この絶対值は Receptance $\alpha_{x x_{A}}$ を知れば，定皘分を実行して容易に求めること ができる。

\section{2. 流路内の乱流の性梊}

2 重管内を水が流れる場合の水流の圧力変動に関す る研究は見当らない。したがって，ここではとの流動 特性の似ている円管内流の結果から 2 重管内流の場合 を推定する。

管内流の水流の圧力変動に関する研究は少なく, $\mathrm{Corcos}^{(9)}$ と Liu が管内流に批方管壁での圧力変動を測定し，そのス ペクトル分布を求めたすのである。第 3 困で低周波領 域 $f \cdot D / \bar{v}<0.1$ では測定データのバラッキが大きい。 さらに，上り低周波領域 $f \cdot D / \bar{v}<0.01$ については明 らかでないか，乱流の性質からしてこの籍围ではスぺ クトル密度は急激に減少すると見做してよい。い末 $f \cdot D / \bar{v}$ の0.01〜 40の符囲を調べてみる。 $D=1 \mathrm{~cm}, \bar{v}=$ $5 \sim 10 \mathrm{~m} / \mathrm{s}$ とすると, $5 \sim 10 \mathrm{~Hz}<f<2,000 \sim 4,000 \mathrm{~Hz}$ と なりこれまでに知られている棒の振動周波数領域を 合み，このような圧力変動が棒の振動の外力として可

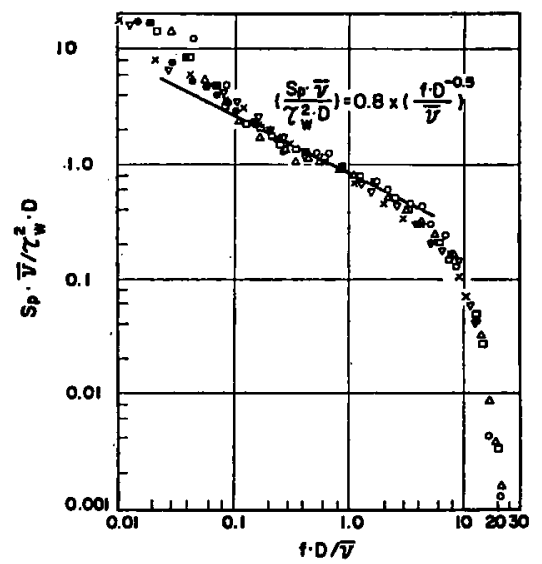

第 3 図管内流における管壁の压力変動 のスペクトル分布
能性の強いことを示している。これるでに全周波数領 域にわたってスペクトル分布を求める式は得られてい ないか，棒の振動が関係すると考えられる周波数領域 数10 数 $100 \mathrm{~Hz}$ に限ってみれば，(6)式の上うに示 されるとしてよい。ただし，(6)式の $S_{p}(f)$ は $R_{p}(\varphi)$ を圧力変動 $p^{\prime}(t)$ の自己相関関数 とすれば，(7)式 で定義される。

$$
\begin{aligned}
& \frac{S_{p}(f) \cdot \bar{v}}{\tau_{w}^{2} \cdot D}=0.8 \times\left(\frac{f \cdot D}{\bar{v}}\right)^{-0.5} \\
& S_{p}(f)=\frac{1}{\pi} \cdot \int_{0}^{\infty} R_{p}(\varphi) \cdot \cos 2 \pi f \varphi \cdot d \varphi
\end{aligned}
$$

(6)式で壁面に括けるせん断応力 $\tau_{w}$ によく知られ た関係式 $(8)$ を用い，さらに内径 $D$ を水力直径 $D_{h}$ に 置き換えることによって( 9 )式を得る。今後 2 重管内 流の圧力変動のスペクトル分布を表わす関係式として （9）式を用いることにする。

$$
\begin{gathered}
\tau_{w}=0.079 \cdot R e^{-0.25} \cdot\left(\frac{\rho_{w} \cdot \bar{v}^{2}}{2}\right) \\
S_{p}(f)=1.25 \times 10^{-3} \cdot\left(\rho_{w} \bar{v}^{2}\right)^{2} \cdot\left(\frac{\nu}{f \cdot \bar{v}^{2}}\right)^{0.5}
\end{gathered}
$$

第 4 図は圧力変動の強さのレイノルズ数による影響 を示したすので(9)，Re $\geq 5 \times 10^{4}$ ではゆるい右下りの直 線で示される。圧力変動の棒への作用の仕方は動的な ちので，この圧力に上る棒の変位を簡単に求めること はできないが，このような圧力变動が枓の振動の外力 の罗当な強さとなっているか否かの概算のためには， 棒にこの圧力変動が静的に作用したと仮定して棒の变 位を求めるのは役立とう。いま記号く >は平均值を

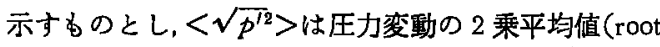
mean square value) を表わするのとし， $<\sqrt{p^{\prime 2}}>/ \tau_{w}$ $=2, R e=10^{5}, \bar{v}=10 \mathrm{~m} / \mathrm{s}, l=100 \mathrm{~cm}, d_{1}=9 \phi, d_{2}=10 \phi$ の ステンレス銅管を両端支持としてその最大変位を求め ると $(\delta / 2)_{\mathrm{st}} \doteqdot 0.26 \mathrm{~mm}$ となり, Burgreen の実験式 (1)加らの結果 $(\delta / 2)_{\mathrm{Bur}} \fallingdotseq 0.19 \mathrm{~mm}$ と比較すると両 者の值は近く，前述のスペクトル分布特性と考方合わ

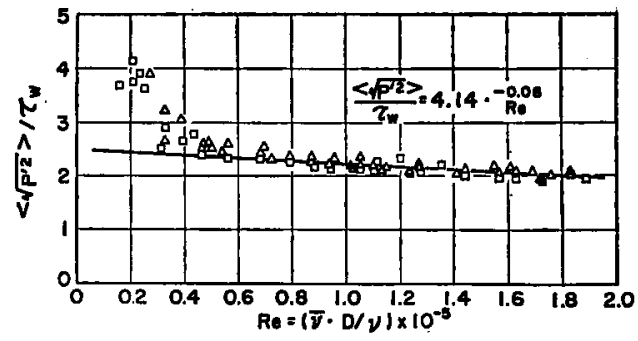

第 4图管内流における管壁の 圧力変動の 2 乗平均值 
せると，水の流動の圧力変動が棒の振動の外力と与る 考えの妥当性を裹付けている。

(5)式の解析でさらに重要な点は, 压力変動 $p^{\prime}(t)$ の流路内の移動速度である。Corcos ${ }^{(9)}$ はこの移動速度 を水の平均流速との比 $v_{p} / \bar{v}$ で求めて括り，それは振 動周波数の関数であるが,ここで関係する数 10 数 100 $\mathrm{Hz}$ の籁囲では $v_{p} / \bar{v}=0.9$ と見做してよい。

\section{3. 水中における棒の横振動}

水中での棒の横振動について，その自然周波数につ いては鬼頭(1)によって求められているが，本報では 異った方法で求めることができたので報告する。さら に強制振動についてはその解を求めた文献は見当らな (.

\section{（1）自然周波数}

棒の水中での自然振動の運動方程式では，通常の慣 性力と弹性力のほかに水の棒に作用する抵抗力を考虑 しなければならない。第 5 図は振動する棒の横断面を 示したひのて，捧が $y$ 方向に振動するとき棒の表面に 働く压力分布 $p_{\theta}$ 沬(10)式で与兄られる(12)。

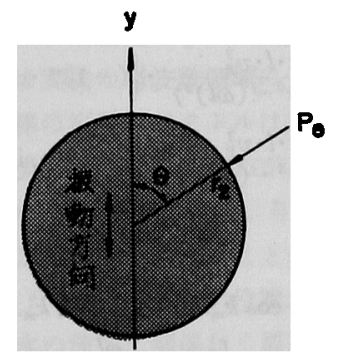

第 5 図振動する棒に働く圧力

したがって、棒の単位長さ当りの抵抗力 $p_{w}$ は (11) 式のよ5にして求められる。

$$
\begin{aligned}
& p_{\theta}=p_{0}+\frac{r_{w}}{2 g} \dot{y}^{2}\left(4 \cos ^{2} \theta-3\right)+\frac{\gamma_{w}}{g} \cdot r_{2} \cdot \ddot{y} \cdot \cos \theta \\
& p_{w}=\int_{0}^{2 \pi} p_{\theta} \cdot r_{2} \cdot \cos \theta \cdot d \theta=\frac{\gamma_{w}}{g} \cdot r_{2}^{2} \cdot \pi \cdot \ddot{y} \\
& \text { たたし } \quad \dot{y}=\frac{d y}{d t}, \ddot{y}=\frac{d^{2} y}{d t^{2}}
\end{aligned}
$$

（11）式の抵抗力を考虑した棒の運動方程式は(12)式と なる。

$$
\frac{\partial^{2} y}{\partial t^{2}}+a^{2} \cdot \frac{\partial^{4} y}{\partial x^{4}}+\frac{g}{A \cdot \gamma_{r}} \cdot p_{w}=0
$$

棒が両端支持の場合の支持端条件 $\left(\left.y\right|_{\substack{x=0 \\ x=l}}=0\right.$, $\left.\partial^{2} y /\left.\partial x^{2}\right|_{\substack{x=0 \\ x=l}}=0\right)$ を満たす正規直交関数系で(12)式の 解を求めることにすると(13)式となり，(11)，(12)式
と共に棒の自然周波数 $\omega_{1 m}$ を決める(14)式が得られ る。(14)式て \{ \}=0 とすることによって，支持端 に括ける水中での棒の自然周波数が(15)式の上うに求 められる。

$$
\begin{aligned}
& y=\sum_{m} A_{m} \cdot \sin \omega_{n m} \cdot t \cdot \sin \frac{m \pi x}{l} \\
& \sum_{n t} A_{m} \cdot\left\{-\omega_{n m}^{2}+\left(\frac{m \pi}{l}\right)^{4} \cdot a^{2}-\left(\frac{\pi r_{2}^{2} \cdot \gamma_{w}}{A \cdot \gamma_{r}}\right) \omega_{n m}^{2}\right\} \\
& \cdot \sin \omega_{n m} t \cdot \sin \frac{m \pi x}{l}=0 \\
& f_{n m}=\frac{\omega_{n m}}{2 \pi}=\frac{(m \pi)^{2}}{2 \pi l^{2}} \cdot a \cdot\left(1+\frac{\pi r_{2}^{2} \gamma_{w}}{A \cdot \gamma_{r}}\right)^{-1 / 2} \\
& m=1,2, \cdots
\end{aligned}
$$

棒が両端固定の場合は，その支持端条件 $\left(\left.y\right|_{\substack{x=0 \\ x=l}}=0\right.$, $\left.\partial y /\left.\partial x\right|_{x=0}=0\right)$ を満たす正規值交関数系は(16)式で与え ることができる。(16)式で固有值 $k_{m} l$ は $\cos k_{m} l \cdot \cosh$ $k_{m} l=1$ の解で $\alpha_{m}$ と共に第 2 表のように与えられ $3^{(13)(14)}$ 。

第 2 表 両端固定の場合の固有値

\begin{tabular}{c|c|c}
\hline$m$ & $\alpha_{m}$ & $k_{m l}$ \\
\hline 1 & 0.9825 & 4.730041 \\
\hline 2 & 1.0008 & 7.853205 \\
\hline 3 & 1.0000 & 10.99561 \\
\hline$m$ & 1.0000 & $\left(m+\frac{1}{2}\right) \cdot \pi$ \\
\hline
\end{tabular}

両端支持の場合と同様に(11)，(12)式と共に棒の自

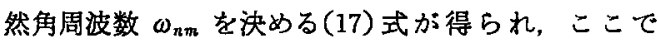
\{\}$=0$ とすることによって固定端の水中での棒の自 然周波数 $f_{n m}$ が(18)式のよ 5 に求められる。

$$
\begin{gathered}
\begin{array}{c}
y=\sum_{m} A_{m} \cdot \sin \omega_{n m} t \cdot X_{m}(x) \\
X_{m}(x)= \\
\quad\left(\cosh k_{m} x-\cos k_{m} x\right) \\
\quad \alpha_{m}\left(\sinh k_{m} x-\sin k_{m} x\right) \\
\sum_{m} A_{m} \cdot\left\{-\omega_{n m}^{2}+a^{2} \cdot k_{m}^{4}-\left(\frac{\pi r_{2}^{2} \cdot \gamma_{w}}{A \cdot \gamma_{r}}\right) \omega_{n m}^{2}\right\} \\
\cdot \sin \omega_{n m} t \cdot X_{m}(x)=0 \\
f_{n m}=\frac{\omega_{n m}}{2 \pi}=\frac{\left(k_{m} l\right)^{4}}{2 \pi l^{2}} \cdot a \cdot\left(1+\frac{\pi r_{2}^{2} \cdot \gamma_{w}}{A \cdot \gamma_{r}}\right)^{-1 / 2} \\
m=1,2, \cdots
\end{array}
\end{gathered}
$$

(15), (18)式を空気中の棒の自然周波数(15) と比べる と, 項 $\left(\pi r_{2}^{2} \gamma_{w} / A \cdot \gamma_{r}\right)$ が水の抵抗の影響を表わして徖 り，水中に捣ける棒の自然周波数が空気中より小さく なることを示している。

（2）強制振動の解

空気中での棒の强制振動については，すでに一般的 
問題として取り扱われてているが(13)(14)，水中の場合に ついてはとの解析例がないので，文献(14)を参考に解を 求める。

第 2 図の上らに $x=x_{\mathrm{A}}$ に处力 $p_{0} e^{i \omega t}$ が作用したと きの棒の運動方程式性，慣性項，弾性項，外力項のほ加 に水の抵抗に上る影響を考㦄しなければいけない。こ の影響については，水中の棒の自然周波数を求めると き示したが，自然振動の場合は棒の振動周波数が解と して求めるすのであるのに対し，强制振動では棒の振 動数は外力の振動数と同一で棒の振幅が求めるものと なるから，水の棒への抵抗も自然振動の場合と異った 形で求められる。Rosenhead ${ }^{(16)}$ によれば，棒が角周波 数 $\omega て ゙$ 振動するとき，水による抵抗は(19)式で与兄ら れる。

$$
\left.\begin{array}{c}
p_{w}=-\frac{\pi r_{2}^{2} \cdot \gamma_{w} \cdot \dot{y}}{g} \cdot i \omega\left(\kappa-i \kappa^{\prime}\right), \\
\kappa=1+2 \sqrt{\frac{2}{\beta}}, \quad \kappa^{\prime}=2 \sqrt{\frac{2}{\beta}}+\frac{2}{\beta}, \quad \beta=\frac{\omega \cdot r_{2}^{2}}{\nu}
\end{array}\right\}
$$

棒の強制振動の形式解は $(20)$ 式で与えられる。ここ で $X_{m}(x)$ は棒の文持端条件を満たす正規直交関数系 で，両端支持では $\sin (m \pi x / l)$ ，両端固定の場合は(16) 式の第 2 の式で与えられる。関数 $\phi_{m}(t)$ は文献(14) 々同様の方法て棒の弾性，慣性，外力扣上び水の抵抗㑆 上る仮想仕事を考えることによって決まる。すなわ ち，このような仮想仕事を考えることによって $\phi_{m}(t)$ を決める方程式(21)加得られる。（21)式で左辺第 2 項 の水の抵抗力に上る仮想仕事恃(19)式と共に定積分 $\int_{0}^{l} p_{w} \delta y \cdot d x$ から求められる。(21)式の解として(22) 式が得られ，これより(20)式と共に解 (23) 式が決ま る。ここで $\omega_{n m}^{\prime}$ は棒の空気中に就ける第 $m$ モードの 自然角周波数である。

$$
\begin{gathered}
\frac{A \cdot l \cdot \gamma_{r}}{g} \cdot \ddot{\phi}_{m}+\frac{\pi r_{2}^{2} \cdot l \cdot \gamma_{w}}{g} \cdot i \omega\left(\kappa-i \kappa^{\prime}\right) \cdot \dot{\phi}_{m} \\
+\frac{\left(k_{m} l\right)^{4}}{l^{3}} \cdot E I \cdot \phi_{m}=P_{0} e^{i \omega t}\left(X_{m}\right)_{x=x_{\Delta}}
\end{gathered}
$$

ただし, $\dot{\phi}=\frac{d \phi}{d t},=\dddot{\phi} \frac{d^{2} \phi}{d t^{2}}$

$$
\begin{aligned}
& \phi_{m}(t)=\left(\frac{g}{A \cdot l \cdot \gamma_{r}}\right) \\
& \cdot \frac{\left(X_{m}\right)_{x=x_{t}}}{\left(\omega_{n m}^{\prime 2}-\omega^{2}\right)-\omega^{2} \frac{\pi r_{2}^{2} \cdot \gamma_{w}}{A \cdot \gamma_{r}}\left(\kappa-i \kappa^{\prime}\right)} \cdot P_{0} e^{i \omega t} \\
& y(x, t)=\left(\frac{g}{A \cdot l \cdot \gamma_{r}}\right) \cdot P_{0} e^{i \omega_{t}}
\end{aligned}
$$

$$
\begin{aligned}
& \cdot \sum_{m} \frac{\left\{\omega_{n m}^{\prime 2}-\omega^{2}\left(1+\kappa \frac{\pi r_{2}^{2} \gamma_{w}}{A \cdot \gamma_{r}}\right)\right\}-i\left(\omega^{2} \kappa^{\prime} \frac{\pi r_{2}^{2} \cdot \gamma_{w}}{A \cdot \gamma_{r}}\right)}{\left\{\omega_{n m}^{\prime 2}-\omega^{2}\left(1+\kappa \frac{\pi r_{2}^{2} \cdot \gamma_{w}}{A \cdot \gamma_{r}}\right)\right\}^{2}+\left(\omega^{2} \kappa^{\prime} \frac{\pi r_{2}^{2} \cdot \gamma_{w}}{A \cdot \gamma_{r}}\right)^{2}} \\
& \cdot\left(X_{m}\right)_{x=x} \cdot\left(X_{m}\right)_{x=x_{A}}
\end{aligned}
$$

(23)式加 Receptance $\left(\alpha x x_{A}=y(x, t) / P_{0} e^{\imath \omega t}\right)$ は 容易に求まり，さらに(5)式右辺の絶対值を求めるた 也定積分を実行した結果を(24)式に示声。(24)式で $\zeta_{2 m}, \zeta_{3}$ は(25)式で与えられ， $\zeta_{1 m}, R e_{m}, I_{m m}$ は両端支持 括よび両端固定に対してそれ発れ(26)，(27)式となる。

$$
\left.\begin{array}{l}
\left|\int_{0}^{l} \alpha_{x x_{A}} \cdot e^{i \omega x_{A}} / v_{p} \cdot d x_{A}\right|^{2} \\
=\left(\frac{g}{A \cdot l \cdot \gamma_{r}}\right)^{2}\left\{\left(\sum_{m} \zeta_{1 m} \frac{\left(\zeta_{2 m} \cdot R e_{m}+\zeta_{3} I_{m m}\right)}{\left(\zeta_{2 m}^{2}+\zeta_{3}^{2}\right)}\right)^{2}\right. \\
\left.\quad+\left(\sum_{m} \zeta_{1 m} \frac{\left(\zeta_{2 m} \cdot I_{m m}+\zeta_{3} \cdot R e_{m}\right)}{\left(\zeta_{2 m}^{2}+\zeta_{3}^{2}\right)}\right)^{2}\right\} \\
\quad \zeta_{2 m}=\omega_{n m}^{\prime 2}-\omega^{2}\left(1+\kappa \frac{\pi r_{2}^{2} \cdot \gamma_{w}}{A \cdot \gamma_{r}}\right) \\
\quad \zeta_{3}=\omega^{2} \kappa^{\prime} \frac{\pi r_{2}^{2} \cdot \gamma_{w}}{A \cdot \gamma_{r}}
\end{array}\right\}
$$

両端支持

$$
\left.\begin{array}{rl}
\zeta_{1 m} & =\sin \frac{m \pi x}{l} \\
R e_{m} & \left.=\frac{2 m \pi \cdot l \cdot v_{p}^{2}}{\left\{\left(m \pi v_{p}\right)^{2}-(\omega l)^{2}\right\}} \cdot\left\{(-1)^{m} \cdot \cos \frac{\omega l}{v_{p}}-1\right\}\right\} \\
I_{m m} & =\frac{2 m \pi \cdot l \cdot v_{p}^{2}}{\left\{\left(m \pi v_{p}\right)^{2}-(\omega l)^{2}\right\}} \cdot\left\{(-1)^{m} \cdot \sin \frac{\omega l}{v_{p}}\right\}
\end{array}\right\}
$$

両端固定

$$
\begin{aligned}
\zeta_{1 m}= & \left(\cosh k_{m} x-\cos k_{m} x\right)-\alpha_{m}\left(\sinh k_{m} x-\sin k_{m} x\right) \\
R e_{m}= & \frac{1}{\left\{k_{m}^{2}+\left(\omega / v_{p}\right)^{2}\right\} \cdot\left\{k _ { m } \cdot \operatorname { c o s } \frac { \omega l } { v _ { p } } \cdot \left(\sinh k_{m} l\right.\right.} \\
& \left.-\alpha_{m} \cdot \cosh k_{m} l\right)+\frac{\omega}{v_{p}} \cdot \sin \frac{\omega l}{v_{p}}\left(\cosh k_{m} l\right. \\
& \left.\left.-\alpha_{m} \sinh k_{m} l\right)\right\} \\
& +\frac{1}{\left\{k_{m}^{2}-\left(\omega / v_{p}\right)^{2}\right\}}\left\{\frac{2 \alpha_{m} \cdot k_{m}^{3}}{\left\{k_{m}^{2}+\left(\omega / v_{p}\right)^{2}\right\}}\right. \\
& \left.-\sin k_{m} l\left(k_{m} \cdot \cos \frac{\omega l}{v_{p}}+\alpha_{m} \cdot \frac{\omega}{v_{p}} \cdot \sin \frac{\omega l}{v_{p}}\right)\right\} \\
I_{m m}= & \frac{1}{\left\{k_{m}^{2}+\left(\omega / v_{p}\right)^{2}\right\}}\left\{k _ { m } \cdot \operatorname { s i n } \frac { \omega l } { v _ { p } } \cdot \left(\sinh k_{m} l\right.\right. \\
& \left.-\alpha_{m} \cdot \cosh k_{m} l\right)-\frac{\omega}{v_{p}} \cdot \cos \frac{\omega l}{v_{p}} \cdot\left(\cosh k_{m} l\right. \\
& \left.\left.-\alpha_{m} \sinh k_{m} l\right)\right\} \\
& +\frac{1}{\left\{k_{m}^{2}-\left(\omega / v_{p}\right)^{2}\right\}}\left\{\frac{2 k_{m}\left(\omega / v_{p}\right)}{\left\{k_{m}^{2}+\left(\omega / v_{p}\right)^{2}\right\}}\right. \\
& \left.-\sin k_{m} l \cdot\left(k_{m} \cdot \sin \frac{\omega l}{v_{p}}-\alpha_{m} \cdot \frac{\omega}{v_{p}} \cdot \cos \frac{\omega l}{v_{p}}\right)\right\}
\end{aligned}
$$




\section{III. 結果の検討}

棒の振動特性は（5）式で，流路内の水の流れの圧力 変動のスペクトル分布を表わす（ 9 式と，水中に批け

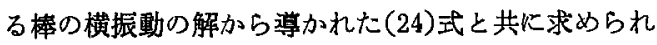
た。ここで得られた結果が，これまでに実験で得た㔞 の振動の性質をどのように説明するか大切な点であ る。そのためには、ここで導いた解が複雑で各種パラ メータの棒の振動に対する影響を式から直接判定でき ないので，具体的問題として数值計算によらなければ ならない。計算例として $l=100 \mathrm{~cm}, d_{1}=9 \phi, d_{2}=10 \phi$, $D_{n}=10 \mathrm{~mm}$ のステンレス鋼管について，その支持区 間の中点 $x=l / 2$ に括ける棒の振動特性を求めて従 来の実験結果と比較する。計算はすべて電子計算機 (IBM 7044)で行なった。

\section{1. 周波数特性}

第 6 図は，水の平均流速が $8.0,9.0 \mathrm{~m} / \mathrm{s}$ のときの棒 の振動のスペクトル分布を両端支持の場合について計 算した結果で，破線の部分は流路内の流れの圧力変動 が不明な領域を示しており，この破線の部分は第 II2節で述べたような理由で $f \rightarrow 0$ に従い $S_{y}(f) \rightarrow 0$ と なる。ここでは実線の周波数領域について考察する。 第6四から，棒の振動スペクトルは周期的山をくりか 点しながら減少してゆくことがかかる。解(24)式恃両 端支持の場合に $f^{*}=m v_{p} / 2 l(m$ : 奇数)で\%の不定形 となるが，ここで確定值を持つことは確認してある。 さらに，この $f^{*}$ の近くに谷が位置することがわかっ た。第 6 図で水の流速に関係なく周期的山と異る鋭い ピークが棒の水中での自然周波数 $f_{n 1}=20.5 \mathrm{~Hz}((15)$ 式)位置にある。こ机は棒の振動でこの近くの周波 数成分が支配的なことを示 L，その位置は(24)式で $\zeta_{2 m}=0$ としたときで，それが棒の水中に怙ける第 1 モ 一ドの自然周波数と一致することは(24)式からす容易 にわかる。第6四のこのよ5な鋭い山は, 棒が選択共

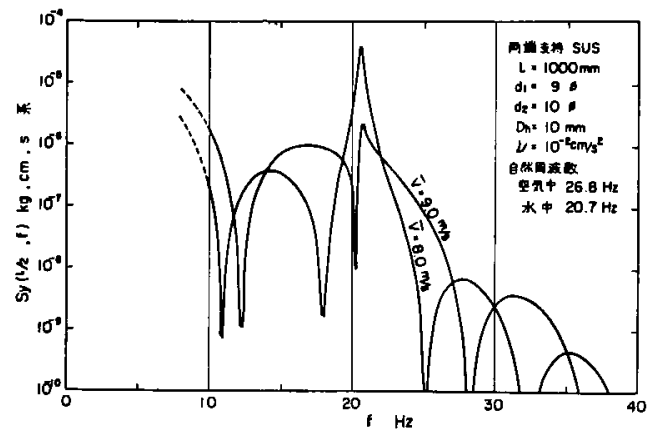

第 6 図棒の振動スペクトル
振を起こしてほとんどその水中での自然周波数に等し い周波数成分だけて振動することが予想される。しか し，このようなピークの位膡が水の流速を変えること に上ってちょ 5 ど周期的な谷と一致したとき(例充 ば第 6 図の $\bar{v}=9.0 \mathrm{~m} / \mathrm{s}$ ) ピークの值は小さくなる。こ のとき棒の振動は 1 つ支配的な振動周波数成分を持 たないので，棒の振動波形は複倠になることが予想さ れる。厳密に山本文に括ける解析モデルと同一条件で はないが，これまでの実験で棒の規則的振動と不規則 的振動が観察されているが，この実験事実す上のよう な解析結果から説明することもできよう。棒が不規則 振動するのは，棒の水中に信梳る自然周波数と周期的 谷との位置が一致したとき，すなわち(28)式でmに任 意の奇数を代入して成り立つときで，さらに(28)式を 波長を入として変形すると(29)式が得られた。これか ら，選択共振は，水の圧力振動で棒の水中に洛ける自 然周波数とちよ 5 ど等しい成分が第 7 図(a)のように作 用したときは起こらず，第7図(b)のよ5に作用したと きに起こることがわかる。

$$
\left.\begin{array}{ll}
f_{m}=\frac{m v_{p}}{2 l} & \text { (両端支持) } \\
f_{m}=\frac{v_{p}}{2 l}\left(m+\frac{1}{2}\right) & \text { (両端固定) }
\end{array}\right\}
$$

両端固定についても，そのスペクトル特性は全く同 じでめる。

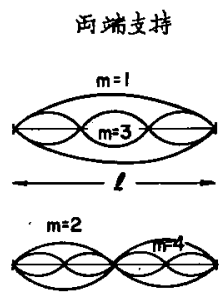

(a)

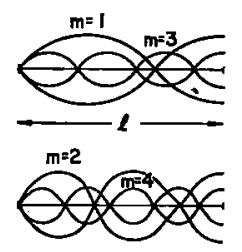

第 7 図 棒への水流の圧力変動の作用

\section{2. 水の流速の影響}

第 8 図は，両端支持の場合について，水の流速に上る 棒の共振周波数に括ける棒の振動スペクトル成分 $S_{v}$ $\left(l / 2, f_{n 1}\right)$ の変化を示したもので, その值は不等周期的 山をくりかえしながら急激に增大してゆく。谷の位置 は(28)式の左辺を $f_{n m}$ に扣きかえることによって求 められ，棒の水中に打方自然周波数と水の流速加ら 決まるこのような谷でも棒は振動しないわけではな 


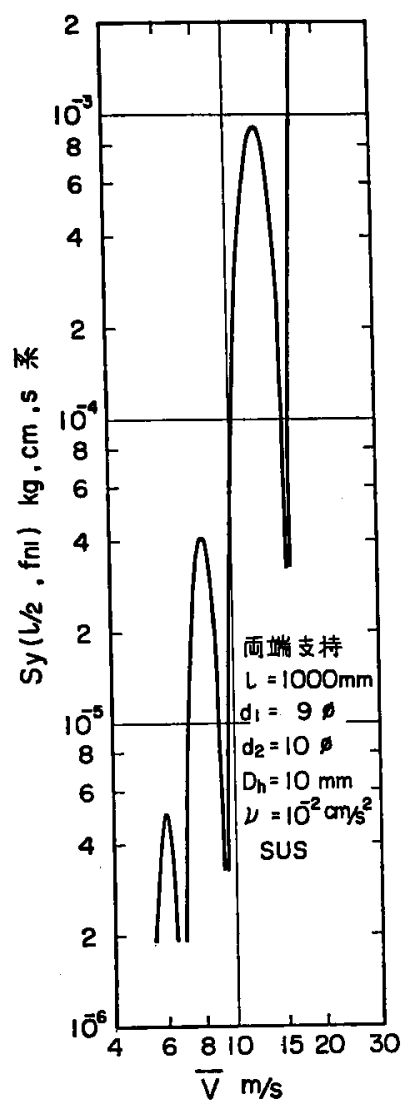

第 8 図棒の振動スペクトルの 水の流速による変化

い。実際は第 6 図に見るよ5な周期的山の効果によっ て，振動波形は複雑となるが棒は振動する。このよう な効果を考虑してる第 8 図の谷が完全に埋まるとは考 えられず，いずれにしてす凹凸をくりかえしながら增 大することに変わりない。ここで，棒の振動スペクト ルに対する流速の影響を見るため，便宜上その山の頂 点を結んでその勾配を求めると，両端支持では $S_{v}\left(f_{n 1}\right)$ $\propto \bar{v}^{6.00}$, 両端固定では $S_{\nu}\left(f_{n 1}\right) \propto \bar{v}^{8.50}$ となり， $S_{\nu}(f)$ $\propto\left\langle y^{2}(t)\right\rangle$ の関係を考虑すると棒の振動の 2 乗平均 值は両端支持で $\left\langle\sqrt{y^{2}(t)}>\propto \bar{v}^{3.45}\right.$, 両端固定て $\left\langle\sqrt{y^{2}(t)}>\propto \bar{v}^{4.25}\right.$ 加綮加れる。この結果はこれま で実験で求められた $\bar{v}^{2.0} \bar{v}^{3.0}$ K比例するとする結 果(第 1 表参照)よりる大きい值である。しかし，例劣 ば Burgreen ${ }^{(2)}$ の実験に見られるように，棒の最大振 幅を流速に対して調へた結果では，両端支持の場合は $\bar{v}^{2.25} \sim \bar{v}^{3.25}$ ，両端固定の場合て $\bar{v}^{2.70} \sim^{5.10}$ の間にあ り,これまでの実験でもその比例指数は確定したるの
でない。またこの指数が棒の支持条件と相関のある ことがわかりここでの結果とその傾向が一致する。 棒のすべての支持条件は両端支持と両端固定の間にあ るから，棒の振幅仙 $\bar{v}^{3.45} \sim \bar{v}^{4.25}$ に比例して固定端に 近いほど大きい値をとる。

\section{3. その他の因子の影部}

棒の支持条件と剛性の影響とは，解(24)式の $\zeta_{2 m} k$ おける棒の自然角周波数 $\omega_{n m}^{l-2.0}$ に比例与る。この傾向 はQuinn 5 ${ }^{(4)}$ Paidoussisら ${ }^{(5)}$ 結果に近いもので、さ らに $\omega_{n m}^{\prime 2} \propto\left(k_{m} l\right)^{4} \cdot(E I)$ の関係を考虑すると，棒の振 幅は固有攧の-2.0乗, 剛性のー0.5 乗に比例し，これ は Burgreenら ${ }^{(2)}$ の結果に近い。

水の粘性係数の棒の振幅に対する影響は，計算から $\mu^{-0.48} \sim \mu^{-0.55}$ に比例して支持端に近い支持条件ほどて の指数の絶対值は大きい。これまでの実験では $\mu^{-0.77}$ $\sim \mu^{-0.80}$ が得られて括り，本報での結果と近い值であ る。

本報では，流路水力淔径の棒の振幅に対する影響は ないとの結果が得られたが(第(9)式参照)，これは本 文の解析が，棒の掁動に対する水の抵抗は棒の周囲が 充分広いとして考㦄したためで，実際の流路の上うに 外管との間隌が狭い場合は，その外管の影響を考虑す る必要がある。また，流路内の水の流れの圧力変動に ついて円管内流の結果を流用したが，今後 2 重管内流 の圧力変動に関する資料が得られれば，さらに実際に 近い解析結果が得られるるのと期待される。

\section{I. ま とめ}

高速炉の燃料要素に見られるょうな，流路内の流れ に平行に置かれた棒の振動機構を提示し，その解析か ら得られた結果をこれまでの実験結果と比較し、ここ での理論によりこれらがよく説明できた。さらにこ れまでの研究で指摘されていない，棒の支持条件の差 虺に上る水の流速の影響の変化についてる明らかにし た。

最後に，本研究全般にわたりご指導いただいた佐野 川好母氏，さらに数式の確認，電子計算機のプログラ 厶作成扣よび予備実験にご協力くださった石黒幸雄， 斉藤直之, 大内光男, 白井甫積の諸氏に感謝の意を表し ます。

\section{[記 号]}

$A$ ：棒の横断面積（中空棒 $=\pi\left(r_{2}^{2}-r_{1}^{2}\right.$ ), 中実棒 $=\pi r_{2}^{2}$ ) 
$a^{2}=E I / A \rho_{r}, \quad D_{h}:$ 流路の水力直徍

$d_{1}, d_{2}$ : 棒の内径亡外径 $\left(r_{1}=d_{1} / 2, r_{2}=d_{2} / 2\right)$

$E:$ 棒の維弾性俰数， $f:$ 周波数 $(\mathrm{Hz})$

$f_{\mathrm{n}}$ : 棒の自然周波数 $(\mathrm{Hz}) ， g$ : 重力口加速度

$I:$ 棒の断面 2 次モーメント， $i=\sqrt{ } \overline{-1}$

$l:$ 棒の支持区間の長さ

$M$ : 水の流路内の箪位長さ当りの質臀

$m$ ：棒の単位長さ当りの質量

$p^{\prime}(t)$ : 流路内の水流の壁面での圧力変動分

$R e:$ レイノルズ数, $=\bar{v} \cdot D_{h} / \nu, \quad t$ : 時間

$\bar{v}$ : 流路内の水の平均流速

$\bar{v}(r)$ : 流路内の水の時間平均流速分布

$v_{p}:$ 流路内の圧力变動の移動速度

$\beta$ ：棒の支持条件によって決まる固有值

$\delta$ : 棒の全振幅, $\gamma$ : 比重量 $(=\rho \cdot g)$

$\rho$ : 密度, $\omega$ : 角周波数 $(=2 \pi f)$

$\omega_{n}$ : 棒の自然角周波数 $\left(=2 \pi f_{n}\right)$

$\mu$ : 水の粘性係数, $\nu$ : 水の動粘性係数

$\tau_{w}$ : 壁面の世ん断応力 $\left(=-\mu(d \bar{v}(r) / d r)_{r=r_{w}}\right)$

添字 $w$ : 水の値, $r$ : 棒の値

$$
\text { 一夌 考 文 献一 }
$$

（1）生田目 健, 佐野川好母, 大内光男：JAERI-memo
2706, (1967).

(2) Burgreen. D., Byrnes, J.J., Benforado. D. M.: Trans. A.S.M.E., 80, 911 (1958).

(3) Pavlica, P.T., Marshall, R.C.: Nucl. Eng. Design, 4, 54 (1966).

(4) QUiNN, E.P.: GEAP-4059, (1962).

(5) PAidoussis, M.P.: $A E C L-2225$, (1965).

(6) 谷一郎: 科 学, 34, 471 (1964).

(7) Hinze,J.O.: "Turbulence", 13 (1959), McGrawHill.

(8) Robson, J.D.: "Random Vibration", 89 (1964), Edinburgh Univ. Press.

(9) Corcos, G.M.: J. Fluid Mech., 18, 353 (1964).

(10) LIU, H.: A.I.Ch.E. J., 13, 644 (1967).

(11) 鬼頭史城: 造船塯会論文集, 116号, 100（昭39）.

(12) Landau, L.D., Lifshitz, E.M.: "Fluid Mechanics", 26 (1963), Pergamon Press.

(13) JAKOBSEN, L.S., AYRE, R.S.：“振動工学”，（昭 36), 丸善.

(14) Timoshenko, S.: "Vibration Problems in Engineering", (1955), Van Nostrand.

(15) 日本機械学会: 機械工学便䜿, 改訂第4版, (1960).

(16) RosenheAD, L.: "Laminar Boundary Layers", 390 (1963), Oxford Univ. Press.

(17) Knudsen, J.G., KATZ, D.L.: "Fluid Dynamics and Heat Transfer", 153 (1958), McGraw-Hill.

\section{改本誌投稿の手引斿}

○一般投稿住研究論文・技術報告・资料・ショー トノートを原則とし，必ず会員の資格を有する。 ○掦載籍囲は，原子力研究に関連する凡ゆる部 門を含め,とくに限定しない。内容はオリシナ ルるのに限る。

○刷上り 6 頁(ショートノートは 2 頁)以内は無 料(有料面は 1 面当り実費的 5,000 円) とする。 和文は「会誌」に、欧文はJournalに掦载される。

○必子゙所定の原稿用紙 (480字詰め, 約 4 枚で 1 頁）使用し，投稿規程に従って執筆する。たた し，欧文は，適宜に厚手のタイプ用紙に 2 段送 り，1枚約25行にタイブする。（約 3 故で 1 頁） 和・欧文とも所定の原稿表紙(無料)を添付する。 図面はそのまま製版できるよ5必ず圔入れトレ 一スナる。（鮮明なゼロックス可）

○投稿希望者は事務局へ連絡すれば，原稿用紙 (30枚程 1 部100円， T45円），投稿規程左送付す 万。

○ 和・欧文を問わず表題・抄録・所属譏関名など を和·英西文で正確に音いて添付する。

○别に䋨切り日は設けない。原稿受理次第「受
理通知」を本人に送る。原稿は当該分野担当の 查読委員の査芜に回わり, 㰠回以後の編集委員 会において採否を審議する。查読通過および揭 载巻号は決定次第通知される。

○論文は查読通過後受理順に掦载される。 （揭载まで欧文約 $3 \sim 4$ 力月，和文約 $8 \sim 9$ 力月）

○別刷は揭载論文 1 篇につき30部まで無料で送 付する(30部以上希望の時は，実費 1 部につき， $50 \sim 100$ 部で 4頁以内 50 円, $5 \sim 8$ 頁 60 円)。

○查誈・蕃議の結果，内容の修正，文章の短縮，ま たは図面の書直しを要求されたり，時には揭载 を遗㦄いたたく場合があるので，予めご了承䫝 いたい。

欧文の修文・添削についてはすへて著者負担 とする。(和訳を要求される場合すおる)

○修正のため返却した原稿は 6 カ中内に再提 出しないと撒回とみなされる。

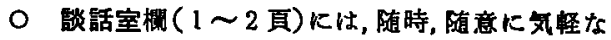
奇稿を歓迎する。

○その他，詳細は事務局へお問い合わせ下さい。 